LETTER TO THE EDITOR

\section{Community-acquired invasive liver abscess syndrome caused by a K1 serotype Klebsiella pneumo- niae isolate in Brazil: a case report of hypervirulent ST23}

\author{
Rosane L Coutinho ${ }^{1 /+}$, Marina F Visconde ${ }^{2}$, \\ Fernanda J Descio ${ }^{1}$, Adriana G Nicoletti ${ }^{2}$, \\ Flavia CL Pinto', Ana Carolina R da Silva ${ }^{2}$, \\ Fernanda Rodrigues-Costa², Ana C Gales², \\ Guilherme HC Furtado ${ }^{1}$
}

\footnotetext{
${ }^{1}$ Grupo de Racionalização do Uso de Antimicrobianos

${ }^{2}$ Laboratório Alerta, Divisão de Doenças Infecciosas, Departamento de Medicina, Universidade Federal de São Paulo, São Paulo, SP, Brasil
}

Hypervirulent Klebsiella pneumoniae (hvKP) strains can cause invasive liver abscess syndrome, which is characterised by liver abscess with extrahepatic complications including central nervous system involvement, necrotising fasciitis or endophthalmitis (Siu et al. 2012). hvKP was first reported in Taiwan in 1985 and, since then, infections caused by hvKP have been described in several parts of the world, with many cases reported in Southeast Asia (Li et al. 2014). In the Americas, invasive liver abscess syndrome has been reported in the United States of America, Canada and Argentina (Siu et al. 2012). However, this strain has not been previously reported in Brazil. Recently, a 57-year-old woman with diabetes mellitus was admitted to the emergency department with a history of fever, nausea, vomiting and mental confusion for five days. On the day of admission, she was comatose, icteric and had a poor general appearance. Her temperature was $37.8^{\circ} \mathrm{C}$ and her blood pressure, pulse and respiratory rate were 110/60 $\mathrm{mmHg}, 96$ beats/min and 48 breaths/min, respectively. Respiratory and cardiovascular auscultations were normal; however, a neurological examination revealed neck rigidity. Bacterial meningitis was suspected and ceftriaxone $2 \mathrm{~g} \mathrm{IV}$ q12 h was empirically prescribed after performing a diagnostic lumbar puncture. Her cerebrospinal fluid (CSF) was xanthochromic and showed glucose $0.0 \mathrm{mg} / \mathrm{dL}$, protein $485 \mathrm{mg} / \mathrm{dL}$ and 8,640 cells $/ \mathrm{mm}^{3}$ (8,121 neutrophils/ $\mathrm{mm}^{3}$ and 259 lymphocytes $/ \mathrm{mm}^{3}$ ). Direct examination

doi: $10.1590 / 0074-0276140196$

RLC and MFV contributed equally to this work.

+Corresponding author: coutinho.infectologia@gmail.com

Received 4 June 2014

Accepted 8 September 2014 of her CSF revealed Gram-negative bacilli. At admission, she also had the following altered laboratory tests: glycaemia $(264 \mathrm{mg} / \mathrm{dL})$, serum creatinine $(2.95 \mathrm{mg} / \mathrm{dL})$, blood urea nitrogen $(152 \mathrm{mg} / \mathrm{dL})$, alkaline phosphatase (177 mg/dL), gamma-glutamyl transferase (138 mg/dL), alanine transaminase $(50 \mathrm{mg} / \mathrm{dL})$, aspartate transaminase (36 mg/dL), total bilirubin (0.59 mg/dL), indirect bilirubin $(0.18 \mathrm{mg} / \mathrm{dL})$, direct bilirubin $(0.41 \mathrm{mg} / \mathrm{dL})$ and international normalised ratio (1.19). Brain and multiple liver abscesses (segments IV, V and VIII) were detected through brain and abdominal computed tomography scans. K. pneumoniae grew on blood (A58300) and CSF (A58301) cultures and both isolates were susceptible to all antimicrobials tested using a BDPhoenix Automated System. The isolates were then submitted to the Alerta Laboratory, Federal University of São Paulo for further characterisation. After surgical drainage of the brain abscess and percutaneous drainage of the liver abscess, the patient's clinical condition deteriorated; ceftriaxone was replaced by meropenem $2 \mathrm{~g} \mathrm{IV} \mathrm{q8} \mathrm{h}$ four days later. Eight days after admission, the patient developed ventilatorassociated pneumonia and K. pneumoniae (also susceptible to all antibiotics tested) and multidrug-resistant Acinetobacter baumannii were isolated from semiquantitative tracheal aspirate cultures. Polymyxin B 1.125.000 UI IV q12 $\mathrm{h}$ was added to the meropenem. Fifteen days later, multidrug-resistant $A$. baumannii bacteraemia was detected despite the use of broad antimicrobial therapy; thus, ampicillin-sulbactam $3 \mathrm{~g}$ IV q6 $\mathrm{h}$ was added to the antimicrobial regimen. At 45 days after admission, the patient died due to septic shock and A. baumannii was again recovered from blood culture. The patient had no previous history of cholelithiasis, liver cirrhosis, malignancies or steroid or chemotherapy use. In addition, the patient had no history of international travel or known contact with Asian individuals.

At Alerta Laboratory, the identification and antimicrobial susceptibility profile of the $K$. pneumoniae strains were confirmed by MALDI-TOF and the agar dilution method. The minimum inhibitory concentration (MIC) results were typically interpreted according to the CLSI (2013); however, The European Committee on Antimicrobial Susceptibility Testing (Breakpoint tables for interpretation of MICs and zone diameters, v.4.0) were used for determining the MIC of polymyxin B. Both isolates showed susceptibility to all antimicrobials tested: amoxicillin-clavulanate ( $\mathrm{MIC} \leq 4 / 2 \mu \mathrm{g} / \mathrm{mL}$ ), ceftazidime $(\mathrm{MIC} \leq 0.25 \mu \mathrm{g} / \mathrm{mL})$, cefepime $(\mathrm{MIC} \leq 0.25 \mu \mathrm{g} /$ $\mathrm{mL}$ ), meropenem (MIC $\leq 0.06 \mu \mathrm{g} / \mathrm{mL}$ ), imipenem (MIC $\leq 0.06 \mu \mathrm{g} / \mathrm{mL}$ ), ertapenem ( $\mathrm{MIC} \leq 0.06 \mu \mathrm{g} / \mathrm{mL}$ ), ciprofloxacin (MIC $\leq 0.06 \mu \mathrm{g} / \mathrm{mL})$, amikacin (MIC $2 \mu \mathrm{g} / \mathrm{mL}$ ), tigecycline (MIC $0.25 \mu \mathrm{g} / \mathrm{mL}$ ), fosfomycin (MIC $16 \mu \mathrm{g}$ / $\mathrm{mL}$ ), piperacillin/tazobactam (MIC $4 \mu \mathrm{g} / \mathrm{mL}$ ) and polymyxin $\mathrm{B}(\mathrm{MIC} \leq 0.125 \mu \mathrm{g} / \mathrm{mL})$. The genetic similarity of the strains was evaluated by pulsed field gel electrophoresis (PFGE) and multilocus sequence typing techniques, as previously described (Tenover et al. 1995, Diancourt et al. 2005). Both strains exhibited identical PFGE patterns and were found to belong to ST23 (Tenover et al. 1995). Genomic DNA was extracted from both isolates (QIAamp DNA Mini Kit, Qiagen ${ }^{\circledR}$ ) and virulence-en- 
TABLE

\begin{tabular}{|c|c|c|c|c|c|}
\hline Factors evaluated & $\begin{array}{l}\text { Target } \\
\text { gene }\end{array}$ & Sequence $\left(5^{\prime}-3^{\prime}\right)$ & $\begin{array}{c}\text { Annealing } \\
\text { temperature } \\
\left({ }^{\circ} \mathrm{C}\right)\end{array}$ & $\begin{array}{l}\text { Amplicom } \\
(\mathrm{pb})\end{array}$ & References \\
\hline \multirow[t]{2}{*}{ Mucoviscosity-associated gene A } & maga- $F$ & CCGATGGTTGGGTTAGCTTT & \multirow[t]{2}{*}{60} & \multirow[t]{2}{*}{801} & \multirow[t]{2}{*}{ This paper } \\
\hline & maga- $R$ & CTGGCCATATTGCTCCGTTG & & & \\
\hline \multirow[t]{2}{*}{ Regulator of mucoid phenotype } & rmpa-F & AGTTAACTGGACTACCTCTGTTTC & \multirow[t]{2}{*}{60} & \multirow[t]{2}{*}{543} & \multirow[t]{2}{*}{ This paper } \\
\hline & rmpa-R & TACTTGGCATGAGCCATCTTT & & & \\
\hline \multirow[t]{2}{*}{ Iron acquisition system } & $k f u-F$ & ATAGTAGGCGAGCACCGAGA & \multirow[t]{2}{*}{60} & \multirow[t]{2}{*}{520} & \multirow{2}{*}{$\begin{array}{c}\text { Yu et al. } \\
(2008)\end{array}$} \\
\hline & $k f u-R$ & AGAACCTTCCTCGCTGAACA & & & \\
\hline \multirow[t]{2}{*}{ Aerobactin } & Aero_1-F & GCATAGGCGGATACGAACAT & \multirow[t]{2}{*}{60} & \multirow[t]{2}{*}{556} & \multirow{2}{*}{$\begin{array}{c}\text { Yu et al. } \\
(2008)\end{array}$} \\
\hline & Aero_1-R & CACAGGGCAATTGCTTACCT & & & \\
\hline \multirow[t]{2}{*}{ Aerobactin } & Aero_2-F & CTGTCGGCATCGGTTTTATT & \multirow[t]{2}{*}{60} & \multirow[t]{2}{*}{531} & \multirow{2}{*}{$\begin{array}{l}\text { Yu et al. } \\
(2008)\end{array}$} \\
\hline & Aero_2-R & TGGCGTGTCGATTATTACCA & & & \\
\hline \multirow[t]{2}{*}{ Thermotolerance phenotype } & $c l p k-F$ & GTTGTGCGACGACCATTACC & \multirow[t]{2}{*}{60} & \multirow[t]{2}{*}{557} & \multirow[t]{2}{*}{ This paper } \\
\hline & clpk-R & TCAGGAAATGCTCTGGACCG & & & \\
\hline
\end{tabular}

sequence of primers used for amplification of virulence encoding genes

coding genes were detected by polymerase chain reaction (PCR) followed by DNA sequencing (Table). Both strains presented a hypermucoviscosity phenotype and possessed magA, rmpA, $k f u$ and aerobactin genes. MagA is a mucoviscosity-associated gene that is related to the extensive production of a polysaccharide capsule and increased resistance to phagocytes. The rmpA gene increases capsular polysaccharide biosynthesis and mucoviscosity. The $k f u$ gene encodes an iron-uptake system that is associated with a hypermucoviscosity phenotype and increased virulence (Ma et al. 2005, Hsu et al. 2011).

As described in this case report, the patient had the classical clinical and microbiological characteristics of community-acquired hvKP: liver abscess with metastatic infections (bacteraemia and meningitis) caused by $K$. pneumoniae displaying a hypermucoviscosity phenotype and belonging to capsular serotypes K1 and ST23, with the presence of the magA and rmpA genes (Chung et al. 2012, Siu et al. 2012). In addition, the patient was diabetic, a risk factor reported by Siu et al. (2012). This clinical case report is important for increasing awareness among Brazilian clinicians with regard to the fact that hvKP ST23 is already circulating in our region and causing serious infections in patients without any previous history of international travel to Asia.

\section{REFERENCES}

Chung DR, Park MH, Kim SH, Ko KS, Kang CI, Peck KR, Song JH 2012. Prevalence and molecular characterization of serotype K1 Klebsiella pneumoniae strains from various clinical specimen sources in 11 Asian countries. J Infect 64: 622-625.
CLSI - Clinical and Laboratory Standard Institute 2013. Performance standards for antimicrobial susceptibility testing, Approved Standard M100-S23. Available from: file://C:/Users/Cliente/ Downloads/CLSI\%202013\%20M100-S23.pdf.

Diancourt L, Passet V, Verhoef J, Grimont PA, Brisse S 2005. Multilocus sequence typing of Klebsiella pneumoniae nosocomial isolates. J Clin Microbiol 43: 4178-4182.

Hsu CR, Lin TL, Chen YC, Chou HC, Wang JT 2011. The role of Klebsiella pneumoniae rmpA in capsular polysaccharide synthesis and virulence revisited. Microbiology 157: 3446-3457.

Li W, Sun G, Yu Y, Ning L, Chen M, Jin R, Jiao Y, Wu H 2014. Increasing occurrence of antimicrobial-resistant hypervirulent (hypermucoviscuous) Klebsiella pneumoniae isolates in China. Clin Infect Dis 58: 225-232.

Ma LC, Fang CT, Lee CZ, Shun CT, Wang JT 2005. Genomic heterogeneity in Klebsiella pneumoniae strains is associated with primary pyogenic liver abscess and metastatic infection. $J$ Infect Dis 192: 117-128.

Siu LK, Yeh KM, Lin JC, Fung CP, Chang FY 2012. Klebsiella pneumoniae liver abscess: a new invasive syndrome. Lancet Infect Dis 12: 881-887.

Tenover FC, Arbeit RD, Goering RV, Mickelsen PA, Murray BE, Persing DH, Swaminathan B 1995. Interpreting chromosomal DNA restriction patterns produced by pulsed-field gel electrophoresis: criteria for bacterial strain typing. J Clin Microbiol 33: 2233-2239.

Yu WL, Ko WC, Cheng KC, Lee CC, Lai CC, Chuang YC 2008. Comparison of prevalence of virulence factors for Klebsiella pneumoniae liver abscesses between isolates with capsular K1/K2 and non-K1/K2 serotypes. Diagn Micr Infec Dis 62: 1-6. 